\title{
Synthesis and antimicrobial activity of Novel Pyrazole Derivatives
}

\author{
HASSAN MOHAMMED AL-GHAMDI* \\ Department of Chemistry, Faculty of Science, Albaha University, Saudi Arabia. \\ ${ }^{*}$ Corresponding author E-mail: hassan11220@gmail.com \\ http://dx.doi.org/10.13005/ojc/350149
}

(Received: October 25, 2018; Accepted: January 20, 2019)

\begin{abstract}
This work aimed to synthesis some new different heterocyclic compounds based on phenylpyrazole-4-carbaldehyde derivative (1) reacted with cyanoacetohydrazide to afford N'-[(5-chloro-3-methyl-1-phenyl-1H-pyrazol-4-yl)methylene]-2-cyanoacetohydrazide (2). It was cyclized by acetyl acetone, and aromatic aldehyde, respectively, to give pyrazolo-pyridone (4) and substituted pyrazolochromene (6 and 8 ), respectively. Pyrazolo triazole (10) was obtained by coupling of 1-azido-4-fluorobenzene with (2), which was diazotized by 3-(chlorodiazenyl)-4,6-dimethyl$-1 \mathrm{H}$-pyrazolo[3,4-b]pyridine to give pyrazolo pyridine derivative (11). N,N-Dimethylformamide dimethyl acetal reacted with (2) to afford [(5-chloro-3-methyl-1-phenyl-1H-pyrazol-4-yl)methylene]-2-cyano-3(dimethylamino)-acrylohydrazide (13). The compound before compound yield substituted pyrazole4-carbohydrazide (15). Also, compound (2) reacted with phNCS in the presence of $\mathrm{KOH}$ and furnish compound (22), which preferred over compound (20) All synthesized compounds were established using IR, ${ }^{1} \mathrm{H}$-NMR. All synthesized compounds were screened for their antimicrobial activities.
\end{abstract}

Keywords: Pyrazole, Thiazole, Chromene, Pyridine and Antimicrobial activity.

INTRODUCTION

Pyrazolos have attracted considerable attention for many researchers, due to their broad effects in many different fields ${ }^{1-2}$, as agrochemicals ${ }^{3-4}$, antimicrobial $^{5}$, antifungal ${ }^{6}$, anticancer ${ }^{7}$, antidiabetic ${ }^{8}$, anti-inflammatory ${ }^{9}$, antitumor ${ }^{10}$, antiviral ${ }^{11}$, anti-HIV activity $^{12}$, and selective enzyme inhibitory activities ${ }^{13}$. Moreover, pyrazolo-chromene derivatives were exhibited powerful antimicrobial and antifungal activities $^{14-15}$. Also, pyrazole compounds based on pyridone ring moiety were evaluated against their antibacterial and antifungal activities pyrazolpyridone derivatives exhibit a positive acceptance as antimicrobial character ${ }^{16-17}$. As well as, when introducing pyrazole and thiazole fragments to parent pyrazol were enhancement antimicrobial power ${ }^{18-21}$. The aim of this work is design and synthesis some a new heterocyclic compound based on pyrazole moiety and investigate their biological evaluation as antimicrobial activities.

\section{MATERIALS AND METHODS}

All chemicals were obtained from SigmaAldrich and used without future purifications. All melting points are uncorrected. IR spectra $(\mathrm{KBr})$ were recorded on FTIR-5300 spectrometer

This is an Open Access article licensed under a Creative Commons Attribution-Non Commercial-Share Alike 4.0 International License (https://creativecommons.org/licenses/by-nc-sa/4.0/), which permits unrestricted Non Commercial use, distribution and reproduction in any medium, provided the original work is properly cited. 
$\left(\lambda_{\max }, \mathrm{cm}^{-1}\right)$. The ${ }^{1} \mathrm{H}-\mathrm{NMR}$ spectra were recorded in $\left(\mathrm{CDCl}_{3} \&\right.$ DMSO- $\left.\mathrm{d}_{6}\right)$ on a Brucker Ultra-Shield 850 $\mathrm{MHz}$ and reported in (ppm).

Synthesis of $\mathrm{N}^{-}-[(5-c h l o r o-3-m e t h y l-1-p h e n y l-1 \mathrm{H}-$ pyrazol-4-yl)methylene]-2-cyanoaceto hydrazide (2)

A mixture of 5-chloro-3-methyl-1-phenyl$1 \mathrm{H}$-pyrazole-4-carbaldehyde $(1 ; 0.02 \mathrm{~mol})$, and 2-cyanoacetohydrazide $(0.02 \mathrm{~mol})$, was refluxed in absolute ethanol $(60 \mathrm{ml})$ for $5 \mathrm{~h}$ at $120^{\circ} \mathrm{C}$. The reaction mixture was cooled, and the solid product was collected, dried. m.p.: $188-190^{\circ} \mathrm{C}$, yield: $5.3 \mathrm{~g}$ (88\%), pale yellow (acetic acid). IR: 1682 (CO), 2263 (CN), $3196(\mathrm{NH}) .{ }^{1} \mathrm{H}-\mathrm{NMR}: \delta=2.55\left(\mathrm{~s}, 3 \mathrm{H}, \mathrm{CH}_{3}\right), 3.85$ $\left(\mathrm{s}, 2 \mathrm{H}, \mathrm{CH}_{2}\right), 7.26-7.84$ (m, 5H, Ar-H), 7.84 (s, $1 \mathrm{H}$, $\mathrm{CH}$ ), 9.60 (s, $1 \mathrm{H}, \mathrm{NH})$. M.F. $\mathrm{C}_{14} \mathrm{H}_{12} \mathrm{CIN}_{5} \mathrm{O}$. Calcd: C, 55.73; H, 4.01; Cl, 11.75; N, 23.21; O, 5.30. Found: C, 55.70; H, 3.38; Cl, 11.79; N, 23.26; O, 5.28.

Synthesis of $\{[(5-c h l o r o-3-m e t h y l-1-p h e n y l-1 \mathrm{H}-$ pyrazol-4-yl)methylene]-amino\}-4,6-dimethyl-2oxo-1,2-dihydropyridine-3-carbonitrile (4)

This compound was prepared by a modification to that previously reported method ${ }^{22}$. A mixture of pyrazole derivative $(2 ; 0.002 \mathrm{~mol})$, acetyl acetone $(0.002 \mathrm{~mol})$ in $(25 \mathrm{ml})$ of absolute ethanol and $0.2 \mathrm{ml}$ of piperidine was added. The reaction mixture was heated under reflux for 3 hours. The solid product formed after cooling was filtered, washed with cold methanol, and dried. m.p.: $235-237^{\circ} \mathrm{C}$, yield: $0.6 \mathrm{~g}(82 \%)$, yellow (benzene). IR: $1652(\mathrm{C}=\mathrm{O}), 2216(\mathrm{CN}){ }^{1} \mathrm{H}-\mathrm{NMR}: \delta=2.43(\mathrm{~s}, 6 \mathrm{H}, 2$ $\mathrm{CH}_{3}$ ), 2.58 (s, 3H, $\mathrm{CH} 3$ ), 6.09 (s, $1 \mathrm{H}, \mathrm{CH}$ pyridine), $7.26-7.55$ (m, 5H, Ar-H) and 8.94 (s, 1H, CH). M.F. $\mathrm{C}_{19} \mathrm{H}_{16} \mathrm{CIN}_{5} \mathrm{O}$. Calcd: C, 62.38; $\mathrm{H}, 4.41 ; \mathrm{Cl}, 9.69 ; \mathrm{N}$, 19.15; O, 4.37. Found: C, 62.32; H, 4.37; Cl, 9.71; N, 19.18; O, 4.35;

Reaction of pyrazole-2-cyanoacetohydrazide with aromatic aldehyde derivatives

Compound (2; $0.002 \mathrm{~mol}$ ) was reacted with aromatic aldehyde derivative $(0.002 \mathrm{~mol})$, in absolute ethanol $(25 \mathrm{ml})$ and $0.3 \mathrm{ml}$ of piperidine was added. The reaction mixture was refluxed for 2-3 $\mathrm{h}$ at $120^{\circ} \mathrm{C}$. The reaction mixture was cooled, and the solid product was collected, and dried.

[(5-chloro-3-methyl-1-phenyl-1 H-pyrazol-4yl)methylene]-2-imino-2H-chromene-3carbohydrazide (6a)

m.p.: $236-238^{\circ} \mathrm{C}$, yield: $0.68 \mathrm{~g}(85 \%)$, yellow (ethanol/benzene). IR: 1688 (CO), 3053, 3296
(NH). ${ }^{1} \mathrm{H}-\mathrm{NMR}: \delta=2.61\left(\mathrm{~s}, 3 \mathrm{H}, \mathrm{CH}_{3}\right), 7.12-7.78$ $(\mathrm{m}, 10 \mathrm{H}, \mathrm{Ar}-\mathrm{H}$, chromene-H) $7.79(\mathrm{~s}, 1 \mathrm{H}, \mathrm{CH})$, 10.01 (s, 1H, NH), 13.49 (s, 1H, NH chromene). M.F. $\mathrm{C}_{21} \mathrm{H}_{16} \mathrm{ClN}_{5} \mathrm{O}_{2}$. Calcd: C, 62.16; H, 3.97; Cl, 8.73; N, 17.26; O, 7.88. Found: C, 62.13; H, 3.96; Cl, 8.77; $\mathrm{N}, 17.25 ; 0,7.89$.

[(5-chloro-3-methyl-1-phenyl-1H-pyrazol-4-yl) methylene]-2-imino-6-methoxy-2H-chromene-3carbohydrazide (6b)

m.p.: $270-272^{\circ} \mathrm{C}$, yield: $0.7 \mathrm{~g}(81 \%)$, orange (acetic acid). IR : 1695 (CO), 3055, $3239(\mathrm{NH})$. ${ }^{1} \mathrm{H}$-NMR: $\delta=2.71\left(\mathrm{~s}, 3 \mathrm{H}, \mathrm{CH}_{3}\right), 3.98\left(\mathrm{~s}, 3 \mathrm{H}, \mathrm{CH}_{3}\right.$ Methoxy), 7.15 - 7.59 (m, 9H, Ar-H , chromene-H) , $8.30(\mathrm{~s}, 1 \mathrm{H}, \mathrm{CH}), 9.04(\mathrm{~s}, 1 \mathrm{H}, \mathrm{NH}), 11.83(\mathrm{~s}$, $1 \mathrm{H}, \mathrm{NH}$ chromene-H) .M.F. $\mathrm{C}_{22} \mathrm{H}_{18} \mathrm{CIN}_{5} \mathrm{O}_{3}$. Calcd: $\mathrm{C}$, $60.62 ; \mathrm{H}, 4.16 ; \mathrm{Cl}, 8.13 ; \mathrm{N}, 16.08 ; \mathrm{O}, 11.01$. Found: C, 60.55; H, 4.12; Cl, 8.14; N, 16.10; O, 11.04 .

6-bromo-[(5-chloro-3-methyl-1-phenyl-1Hpyrazol-4-yl)methylene]-2-imino-2H-chromene3-carbohydrazide (6c)

m.p.: $248-250^{\circ} \mathrm{C}$, yield: $0.82 \mathrm{~g}(86 \%)$, yellow (ethanol). IR: 1681 (CO), $3213(\mathrm{NH})$. M.F. $\mathrm{C}_{21} \mathrm{H}_{15} \mathrm{BrClN}_{5} \mathrm{O}_{2}$. Calcd: C, 52.03; H, 3.12; $\mathrm{Br}, 16.48$; $\mathrm{Cl}, 7.31 ; \mathrm{N}, 14.45 ; \mathrm{O}, 6.61$. Found: C, 51.98; H, 3.11; $\mathrm{Br}, 16.42 ; \mathrm{Cl}, 7.32 ; \mathrm{N}, 14.43 ; \mathrm{O}, 6.60$.

Synthesis of [(5-chloro-3-methyl-1-phenyl-1Hpyrazol-4-yl)methylene]-3-imino-3H-benzo[f] chromene-2-carbohydrazide (8)

The compound $(2 ; 0.002 \mathrm{~mol})$ was cyclized by 2-hydroxy-1-napthaldehyde $(0.002 \mathrm{~mol})$ in absolute ethanol media $(20 \mathrm{ml})$ with catalytic amount of piperidine. The reaction mixture was heated under reflux for $3 \mathrm{~h}$, the solid product formed was filtered, washed with cold methanol, and dried. m.p.: $242-244^{\circ} \mathrm{C}$, yield: $0.73 \mathrm{~g}(80 \%)$, pale yellow (ethanol/ benzene) IR: 1689 (CO), 3049, 3242 (NH). M.F. $\mathrm{C}_{25} \mathrm{H}_{18} \mathrm{ClN}_{5} \mathrm{O}_{2}$. Calcd: C, 65.86; H, 3.98; $\mathrm{Cl}, 7.78 ; \mathrm{N}$, 15.36; O, 7.02. Found: C, 65.78; H, 3.94; Cl, 7.76; $\mathrm{N}, 15.38 ; 0,7.01$.

Synthesis of 5-amino[(5-chloro-3-methyl-1phenyl-1H-pyrazol-4-yl)methylene]-1-(4-fluorophenyl)-1H-1,2,3-triazole-4-carbohydrazide (10)

1-azido-4-fluorobenzene $(0.001 \mathrm{~mol})$ was dissolved in absolute ethanol $(20 \mathrm{ml})$. Compound (2; $0.001 \mathrm{~mol}$ ), in presence of $1.2 \mathrm{~g}$ of sodium ethoxide was added to the reaction mixture. Then heated under reflux for about $3 \mathrm{~h}$, the solid 
product was filtered, washed with cold ethanol, and dried. m.p.: $280-282^{\circ} \mathrm{C}$, yield: $0.33 \mathrm{~g}(75 \%)$, white (1,4-dioxane). IR: 1640 (CO), $3275(\mathrm{NH}), 3422$, $4552\left(\mathrm{NH}_{2}\right) .{ }^{1} \mathrm{H}-\mathrm{NMR}: \delta=2.51\left(\mathrm{~s}, 3 \mathrm{H}, \mathrm{CH}_{3}\right), 6.59$ $\left(\mathrm{s}, 2 \mathrm{H}, \mathrm{NH}_{2}\right), 6.46-7.71(\mathrm{~m}, 9 \mathrm{H}, \mathrm{Ar}-\mathrm{H}), 8.57$ (s, $1 \mathrm{H}, \mathrm{CH}), 11.91$ (s, $1 \mathrm{H}, \mathrm{NH}$ ). M.F. $\mathrm{C}_{20} \mathrm{H}_{16} \mathrm{CIFN}_{8} \mathrm{O}$. Calcd : C, 54.74; H, 3.68; Cl, 8.08; F, 4.33; N, 25.50; O, 3.65. Found: C, 54.69; H, 3.64; Cl, 8.10; F, 4.34; N, 25.57; O, 3.62.

Synthesis of \{2-[2-(5-chloro-3-methyl-1-phenyl1H-pyrazol-4-yl)methyl-ene] hydrazinyl\}-N-(4,6dimethyl-1H-pyrazolo[3,4-b]pyridin-3-yl)-2oxoacetohydrazonoyl cyanide (11)

A mixture of pyrazole derivative $(2 ; 0.001$ mol) and 3-(chlorodiazenyl)-4,6-dimethyl-1 $\mathrm{H}$ pyrazolo[3,4-b]pyridine $(0.001 \mathrm{~mol})$, in pyridine $(15 \mathrm{ml})$. The reaction mixture was stirred at $0^{\circ} \mathrm{C}$ for $3 \mathrm{~h}$, then poured into ice cold water. The solid product was collected and dried. m.p.: $244-246^{\circ} \mathrm{C}$, yield: 0.4 g (85\%), green (ethanol/benzene). IR: 1652 (CO), $2217(\mathrm{CN}), 3212,3262.3403(\mathrm{NH}) .{ }^{1} \mathrm{H}-\mathrm{NMR}: \delta=$ $2.70\left(\mathrm{~s}, 3 \mathrm{H}, \mathrm{CH}_{3}\right), 2.92\left(\mathrm{~s}, 3 \mathrm{H}, \mathrm{CH}_{3}\right), 3.18(\mathrm{~s}, 3 \mathrm{H}$, $\left.\mathrm{CH}_{3}\right), 7.15-7.59(\mathrm{~m}, 6 \mathrm{H}, \mathrm{Ar}-\mathrm{H}), 8.28(\mathrm{~s}, 1 \mathrm{H}, \mathrm{CH})$, $8.28(\mathrm{~s}, 1 \mathrm{H}, \mathrm{NH}), 9.35$ and $11.03(\mathrm{~s}, 2 \mathrm{H}, \mathrm{NH})$. M.F. $\mathrm{C}_{22} \mathrm{H}_{19} \mathrm{CIN}_{10}$ O. Calcd: C, 55.66; H, 4.03; Cl, 7.46; N, 29.48; O, 3.37. Found: C, 55.57; H, 3.98; Cl, 7.47; N, 29.51; O, 3.36.

General procedure for Reaction of pyrazole-2cyanoacetohydrazide with benzenediazonium chloride derivatives

Pyrazole derivative $(2 ; 0.001 \mathrm{~mol})$ and 1-chloro-2-phenyldiazene derivative $(0.001 \mathrm{~mol})$ was dissolved in $(15 \mathrm{ml})$ of pyridine. The reaction mixture was stirred at $0^{\circ} \mathrm{C}$ for $2 \mathrm{~h}$ and poured into ice cold water. The solid product was collected and dried.

2-\{2[-(5-chloro-3-methyl-1-phenyl-1H-pyrazol4-yl) methylene]hydrazinyl\}-2-oxo-N-phenyl acetohydrazonoyl cyanide (12a)

m.p.: $196-197^{\circ} \mathrm{C}$, yield: $0.35 \mathrm{~g}(87 \%)$, red (ethanol) .IR : 1667 (CO) , $2220(\mathrm{CN}), 3042,3256$ (NH). ${ }^{1} \mathrm{H}-\mathrm{NMR}: \delta=2.65\left(\mathrm{~s}, 3 \mathrm{H}, \mathrm{CH}_{3}\right), 7.18-7.99$ (m, 10H , Ar-H), $8.16(\mathrm{~s}, 1 \mathrm{H}, \mathrm{CH}), 9.17$ and 14.14 (s, $2 \mathrm{H}, \mathrm{NH}$ ) . M.F. $\mathrm{C}_{20} \mathrm{H}_{16} \mathrm{CIN}_{7} \mathrm{O}$. Calcd: C, 59.19; H, 3.97; Cl, 8.73; N, 24.17; O, 3.94. Found: C, 59.13; $\mathrm{H}, 3.94 ; \mathrm{Cl}, 8.75 ; \mathrm{N}, 24.12$; O, 3.94 .
2-\{2-[(5-chloro-3-methyl-1-phenyl-1H-pyrazol-4yl)methylene]hydrazinyl\}-N-(4-chlorophenyl)-2oxoacetohydrazonoyl cyanide (12b)

m.p.: $248-250^{\circ} \mathrm{C}$, yield: $0.35 \mathrm{~g}(81 \%)$, yellow (benzene). IR: 1666 (CO), 2220 (CN), 3035, 3256 (NH). M. F. $\mathrm{C}_{20} \mathrm{H}_{15} \mathrm{Cl}_{2} \mathrm{~N}_{7} \mathrm{O}$. Calcd: C, $54.56 ; \mathrm{H}, 3.43 ; \mathrm{Cl}$, 16.10; N, 22.28; O, 3.63. Found: C, 54.59; H, 3.37; $\mathrm{Cl}, 16.12 ; \mathrm{N}, 22.30 ; \mathrm{O}, 3.61$.

Synthesis of [(5-chloro-3-methyl-1-phenyl-1Hpyrazol-4-yl)methyl-ene]-2-cyano-3-(dimethylamino) acrylohydrazide (13)

$\mathrm{N}, \mathrm{N}$-dimethylformamide dimethyl acetal $(0.001 \mathrm{~mol})$ was added to pyrazole derivative (2; $0.001 \mathrm{~mol})$, in xylene $(15 \mathrm{ml})$. The reaction mixture was refluxed for $4 \mathrm{~h}$ at $220^{\circ} \mathrm{C}$. The reaction mixture was cooled, and the solid product was collected and dried. m.p.: $230-232^{\circ} \mathrm{C}$, yield: $0.32 \mathrm{~g}(89 \%)$, pale yellow (1,4-dioaxne). IR: 1674 (CO), 2181 (CN), $3340(\mathrm{NH}) .{ }^{1} \mathrm{H}-\mathrm{NMR}: \delta=2.61\left(\mathrm{~s}, 3 \mathrm{H}, \mathrm{CH}_{3}\right), 3.39(\mathrm{~s}$, $\left.3 \mathrm{H}, \mathrm{CH}_{3}\right), 3.41(\mathrm{~s}, 3 \mathrm{H}, \mathrm{CH} 3), 7.23-7.93(\mathrm{~m}, 6 \mathrm{H}, \mathrm{Ar}-\mathrm{H}$ and $\mathrm{CH}$ ), $8.94(\mathrm{~s}, 1 \mathrm{H}, \mathrm{CH}), 10.00(\mathrm{~s}, 1 \mathrm{H}, \mathrm{NH}) . \mathrm{M}$. F. $\mathrm{C}_{17} \mathrm{H}_{17} \mathrm{ClN}_{6} \mathrm{O}$. Calcd: C, $57.23 ; \mathrm{H}, 4.80 ; \mathrm{Cl}, 9.94$; $\mathrm{N}, 23.55 ; \mathrm{O}, 4.48$. Found: C, 57.16; H, 4.77; Cl, 9.90; N, 23.60; O, 4.43.

Synthesis of 3-amino[(5-chloro-3-methyl-1phenyl-1H-pyrazol-4-yl)methylene]-1H-pyrazole4-carbohydrazide (15)

A mixture of $(13 ; 0.001 \mathrm{~mol})$, hydrazine hydrate $(0.001 \mathrm{~mol})$, in $(15 \mathrm{ml})$ of 1 , 4-dioxane. The reaction mixture was heated under reflux for $7 \mathrm{~h}$, the solid product is filtered, washed with cold ethanol, and dried. m.p.: $105-106^{\circ} \mathrm{C}$, yield: $0.28 \mathrm{~g}(87 \%)$ white (ethanol). IR: 1597, $1633(\mathrm{C}=\mathrm{N}), 3208,3364\left(\mathrm{NH}_{2}\right)$. ${ }^{1} \mathrm{H}-\mathrm{NMR}: \delta=2.56\left(\mathrm{~s}, 3 \mathrm{H}, \mathrm{CH}_{3}\right), 5.40\left(\mathrm{~s}, 2 \mathrm{H}, \mathrm{NH}_{2}\right)$ and $7.19-7.51(\mathrm{~m}, 7 \mathrm{H}, \mathrm{Ar}-\mathrm{H}), 7.67(\mathrm{~s}, 1 \mathrm{H}, \mathrm{CH})$ and 8.59 (s, 2H, NH). M.F. $\mathrm{C}_{15} \mathrm{H}_{14} \mathrm{CIN}_{7} \mathrm{O}$. Calcd: C, 52.39; H, 4.08; Cl, 10,34; N, 28.53; O, 4.66. Found: C, 52.35; $\mathrm{H}, 4.10 ; \mathrm{Cl}, 10.31 ; \mathrm{N}, 28.54 ; \mathrm{O}, 4.62$.

General Procedure for [(5-chloro-3-methyl-1phenyl-1H-pyrazol-4-yl)methylene]-2-cyano2-(4-hydroxy-3-phenylthiazol-2(3H)-ylidene)acetohydrazi de (22)

To suspension of potassium hydroxide (0.01 mol) in dry DMF (10 ml) Pyrazole derivative (2; $0.01 \mathrm{~mol}$ ) was added during stirring, phenyl isothiocyanate $(0.01 \mathrm{~mol})$ was dropped slowly to the reaction mixture. After completing of addition, stirring of the reaction mixture was continued for 5 hours. 
Then treated with ethyl bromoacetate $(0.01 \mathrm{~mol})$ and the stirring was continued at room temperature for 4 hours. The mixture was then triturated with cold $\mathrm{H}_{2} \mathrm{O}(100 \mathrm{ml})$ containing $\mathrm{HCl}(0.1 \mathrm{~N})$. The resultant solid product was collected by filtration and dried. m.p.: $198-199^{\circ} \mathrm{C}$, yield: $0.4 \mathrm{~g}(84 \%)$, red (ethanol). IR: 1734 (CO), $2201(\mathrm{CN}), 3254(\mathrm{NH}) .{ }^{1} \mathrm{H}-\mathrm{NMR}: \delta$ $=2.58\left(\mathrm{~s}, 3 \mathrm{H}, \mathrm{CH}_{3}\right), 4.15\left(\mathrm{~s}, 2 \mathrm{H}, \mathrm{CH}_{2}\right), 7.25-7.55$ (m, 10H , Ar-H), $8.04(\mathrm{~s}, 1 \mathrm{H}, \mathrm{CH}), 9.97(\mathrm{~s}, 1 \mathrm{H}, \mathrm{NH})$ .M.F. $\mathrm{C}_{23} \mathrm{H}_{17} \mathrm{CIN}_{6} \mathrm{O}_{2}$ S. Calcd: C, 57.93; H, 3.59; Cl, 7.43; N, 17.62; O, 6.71; S, 6.72 . Found: C, 57.96; H, $3.54 ; \mathrm{Cl}, 7.41 ; \mathrm{N}, 17.64 ; \mathrm{O}, 6.70 ; \mathrm{S}, 6.71$.

\section{Antimicrobial activity}

The standardized disc - agar diffusion method was followed to determine the activity of the synthesized compounds against the tested microorganisms.

\section{Test Organisms}

Cultures of the following microorganism were used in the test: Gram-positive bacteria: Staphylococcus aureus (ATCC25923) and Bacillus subtilis (ATCC6635), Gram-negative bacteria: Escherichia coli (ATCC 25922) and Salmonella typhimurium (ATCC 14028), Yeast: Candida albicans (ATCC 10231) and Fungus: Aspergillus fumigatus.

\section{Screening for the antimicrobial potential Preparation of tested compound}

The tested compounds were dissolved in dimethyl formamide (DMF) solvent and prepared in two concentrations; 100 and $50 \mathrm{mg} / \mathrm{ml}$ and then $10 \mu \mathrm{l}$ of each preparation was dropped on disk of $6 \mathrm{~mm}$ in diameter and the concentrations became 1 and $0.5 \mathrm{mg} /$ disk respectively. In the case of insoluble compounds, the compounds were suspended in DMF and vortexed then processed.

\section{Testing for anti-bacterial and yeast activity}

Bacterial cultures were grown in nutrient broth medium at $30^{\circ} \mathrm{C}$. After $16 \mathrm{~h}$ of growth, each microorganism, at a concentration of 108 cells $/ \mathrm{mL}$, was inoculated on the surface of Mueller-Hinton agar plates using sterile cotton swab. Subsequently, uniform size filter paper disks (6 $\mathrm{mm}$ in diameter) were impregnated by equal volume $(10 \mu \mathrm{l})$ from the specific concentration of dissolved compounds and carefully placed on surface of each inoculated plate.
The plates were incubated in the upright position at $36^{\circ} \mathrm{C}$ for 24 hours. Three replicates were carried out for each extract against each of the test organism. Simultaneously, addition of the respective solvent instead of dissolved compound was carried out as negative controls. After incubation, the diameters of the growth inhibition zones formed around the disc were measured with transparent ruler in millimeter, averaged and the mean values were tabulated.

\section{Anti-fungal activity}

Active inoculum for experiments were prepared by transferring many loopfuls of spores from the stock cultures to test tubes of sterile distilled water (SDW) that were agitated and diluted with sterile distilled water to achieve optical density corresponding to $2.0 \times 10^{5} \mathrm{spore} / \mathrm{ml}$. inoculum of $0.1 \%$ suspension was swabbed uniformly and the inoculum was allowed to dry for $5 \mathrm{~min}$ then the same procedure was followed as described above.

\section{Standard references}

The antibiotic chloramphenicol was used as standard reference in the case of Gram-negative bacteria, Cephalothin was used as standard reference in the case of Gram-positive bacteria and cycloheximide was used as standard reference in the case of yeasts and fungi.

\section{RESULTS AND DISCUSSION}

\section{Chemistry}

The starting material $\mathrm{N}$ '-[(5-chloro-3methyl-1-phenyl-1H-pyrazol-4-yl)methylene]-2cyanoacetohydrazide (2) was prepared via the reaction of 5-chloro-3-methyl-1-phenyl-1H-pyrazole4-carbaldehyde (1) with 2-cyanoacetohydrazide as shown in (Scheme 1). The proposed (IR) spectrum of compound showed a prominent peak at $2263 \mathrm{~cm}^{-1}$ assigned for $(\mathrm{CN})$. Whereas the ${ }^{1} \mathrm{H}-\mathrm{NMR}\left(\mathrm{CDCl}_{3}\right)$ show signals at $\delta=3.85 \mathrm{ppm}$ characteristics for $-\mathrm{CH}_{2}$ - and at $9.60 \mathrm{ppm}$ for $\mathrm{NH}$. when Treatment of N'-[(5-chloro-3-methyl-1-phenyl-1H-pyrazol-4-yl) methylene]-2-cyanoacetohydrazide (3) with acetyl acetone afforded the corresponding pyrazolopyridone (4). The ${ }^{1} \mathrm{H}-\mathrm{NMR}$ showed a signals at $\delta=2.43 \mathrm{ppm}$ characteristics for two methyl and at 6.09 ppm stands for $\mathrm{CH}$ in pyridine. 


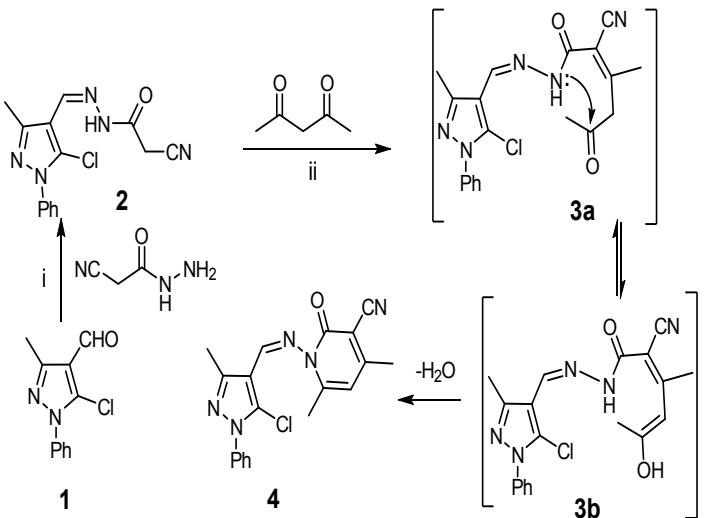

Scheme 1. Reagents and conditions: i-Ethanol, reflux 4-5 h ii-Ethanol/pip, reflux 3 hours

However, reaction of (2) with salicaldehyde or its derivatives in ethanol in the presence of piperidine as a catalyst under reflux via elimination of water was afforded the corresponding [(5-chloro-3-methyl1-phenyl-1H-pyrazol-4-yl)methylene]-2-imino-2Hchromene-3-carbohydrazide derivatives (6) via the plausible intermediate (5) as shown in (Scheme 2) The disappearance of absorption characteristics band for $\mathrm{CN}$ group at $2263 \mathrm{~cm}^{-1}$ in 2, and appearance of characteristics for $\mathrm{NH}$ at band $3296 \mathrm{~cm}^{-1}$, that supported structure (6a) . The other evidence supported (6a), disappearance of characteristic $-\mathrm{CH}_{2}$-signal (3.85 $\mathrm{ppm}$ ), and presence of a characteristic signal for chromene-NH proton at $13.49 \mathrm{ppm}$. Also, The ${ }^{1} \mathrm{H}-\mathrm{NMR}$ of compound $(6 \mathrm{~b})$ revealed a characteristic signal for $\mathrm{CH}_{3}$ of methoxy at $3.89 \mathrm{ppm}$.

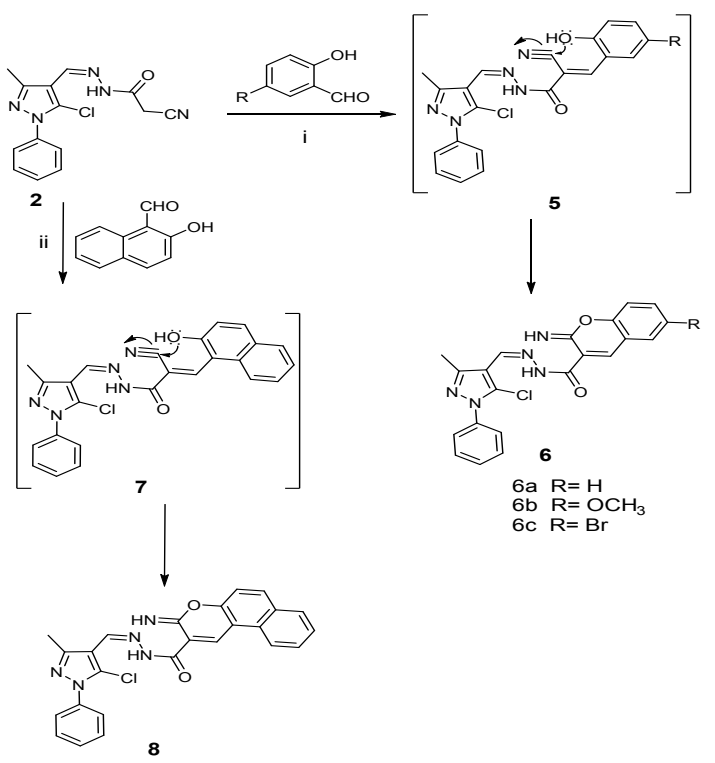

Scheme 2. Reagent and conditions: i-Ethanol/pip, reflux 2-3 $\mathrm{h}$ ii-Ethanol/pip, reflux 3 hours
Moreover, coupling of (2) with 1-azido-4fluorobenzene in presence of sodium ethoxide as a catalyst, which yielded the corresponding triazole derivative (10). The formation of triazole derivative (10) was assumed to be formed via the acyclic intermediate (9), which then cyclized via addition of amino group to a cyano group (Scheme 2). The infrared (IR) spectrum revealed the disappearance of an absorption band for a characteristic for $\mathrm{CN}$ group at $2263 \mathrm{~cm}^{-1}$, in addition to appearance of absorption band characteristics for $\mathrm{NH}_{2}$ at 3422 and $4552 \mathrm{~cm}^{-1}$. ${ }^{1} \mathrm{H}-\mathrm{NMR}$ showed the disappearance of signal at $3.85 \mathrm{ppm}$ characteristic for $-\mathrm{CH}_{2}$ - with presence of a characteristic signal at $6.59 \mathrm{ppm}$ for $\mathrm{NH}_{2}$ group, which supported compound (10).

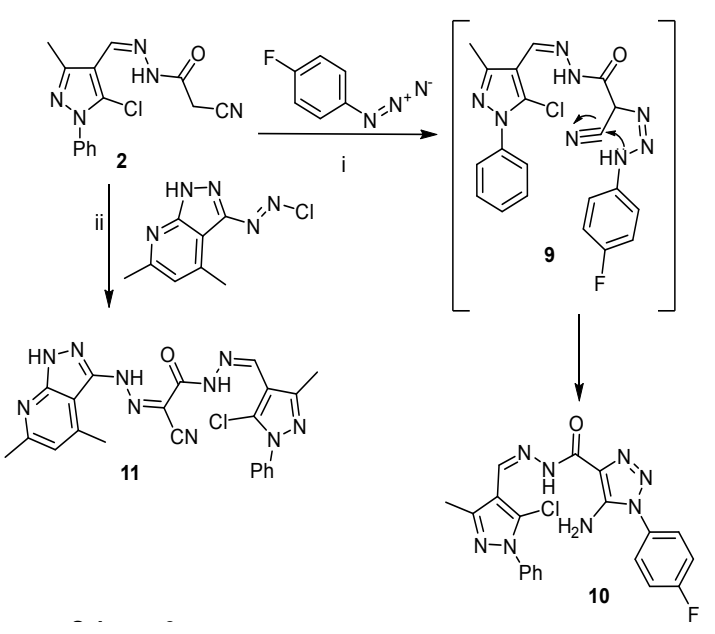

Scheme 3. Reagent and conditions: i-Ethanol/EtONa, reflux $3 \mathrm{~h}$ ii-Pyridine $/ 0^{\circ} \mathrm{C}$ stirrer 3 hours

As well as, reaction of 3-(chlorodiazenyl)4,6-dimethyl-1H-pyrazolo[3,4-b]pyridine in pyridine afforded (11) via elimination of hydrogen chloride. ${ }^{1} \mathrm{H}$ NMR $\left(\mathrm{CDCl}_{3}\right)$ spectrum of compound (11) revealed the disappearance of characteristic for $-\mathrm{CH}_{2}$ signal at $3.85 \mathrm{ppm}$ - with appearance of characteristic new -NH signal at $11.03 \mathrm{ppm}$.

Also, reaction of benzenediazonium chloride derivative gave $(12 a, 12 b)$, as shown in (Scheme 3). The infrared (IR) spectrum showed prominent peak at $3256 \mathrm{~cm}^{-1}$ assigned for (NH). ${ }^{1} \mathrm{H}-\mathrm{NMR}$ exhibited the disappearance of signal at $3.85 \mathrm{ppm}$ characteristic for $-\mathrm{CH}_{2}$ - with appearance of signal at $14.14 \mathrm{ppm}$ characteristic for the new NH. Reaction of pyrazole derivative (2) with 
$\mathrm{N}, \mathrm{N}$-Dimethylformamide dimethyl acetal in xylene was afforded[(5-chloro-3-methyl-1-phenyl-1Hpyrazol-4-yl)methylene]-2-cyano-3-(dimethylamino)acrylohydrazide (13) via elimination of two methanol molecules. ${ }^{1} \mathrm{H}$-NMR $\left(\mathrm{CDCl}_{3}\right)$ spectrum of compound (13) revealed the disappearance of signal at 3.85 ppm characteristic for $-\mathrm{CH}_{2}-$ with absorption signal at $7.23 \mathrm{ppm}$ characteristic for $\mathrm{CH}$.

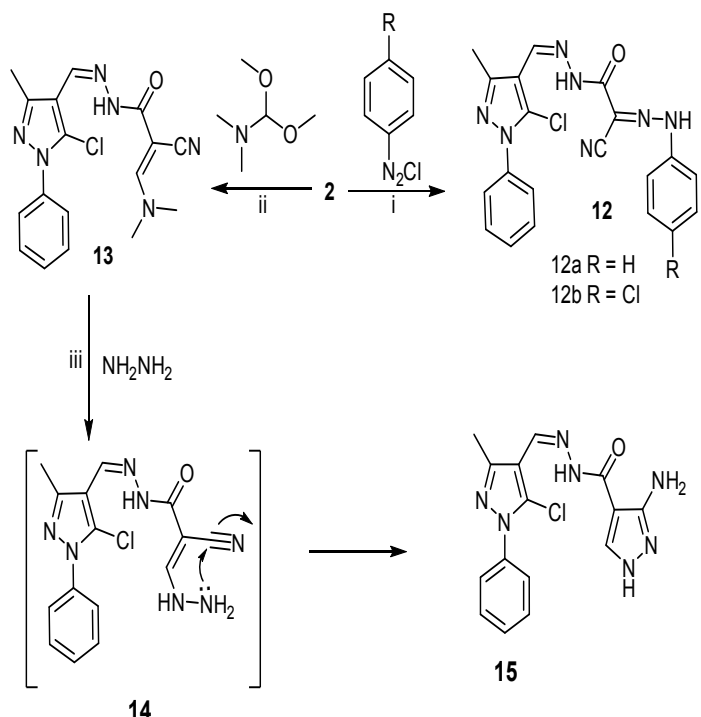

Scheme 4. Reagent and conditions: i-Pyridine $/ 0^{\circ} \mathrm{C}$, stirrer $2 \mathrm{~h}$ ii-Xylene, reflux $4 \mathrm{~h}$ iil-1,4-Dioxane, reflux 7 hours

The reaction of (13) with hydrazine hydrate in 1,4-dioxane resulted in formation of 3-amino[(5chloro-3-methyl-1-phenyl-1H-pyrazol-4-yl)methylene]$1 \mathrm{H}$-pyrazole-4-carbohydrazide (15) via elimination of dimethylamine, then a cycloaddition reaction, which led to final product, as shown on (Scheme 4). The infrared (IR) spectrum showed presence of characteristics for $\mathrm{NH}_{2}$ bands at $3208,3364 \mathrm{~cm}^{-1}$.

Compound (2) reacted with phenyl isothiocyanate in presence of potassium hydroxide afforded an intermediate product of potassium $-\{2-[-(5-c h l o r o-3-m e t h y l-1-$ phenyl-1H-pyrazol4-yl)methylene] hydrazinyl\}-2-cyano-3-oxo-1(phenylamino)prop-1-ene-1-thiolate (16), which, reacted with ethyl bromoacetate at room temperature to give [(5-chloro-3-methyl-1-phenyl-1H-pyrazol-4-yl) methylene)-2-cyano-2-(4-hydroxy-3-phenylthiazol$2(3 \mathrm{H})$-ylidene)acetohydrazide (22) as showed in (Scheme 5). It can concluded that from the obtained

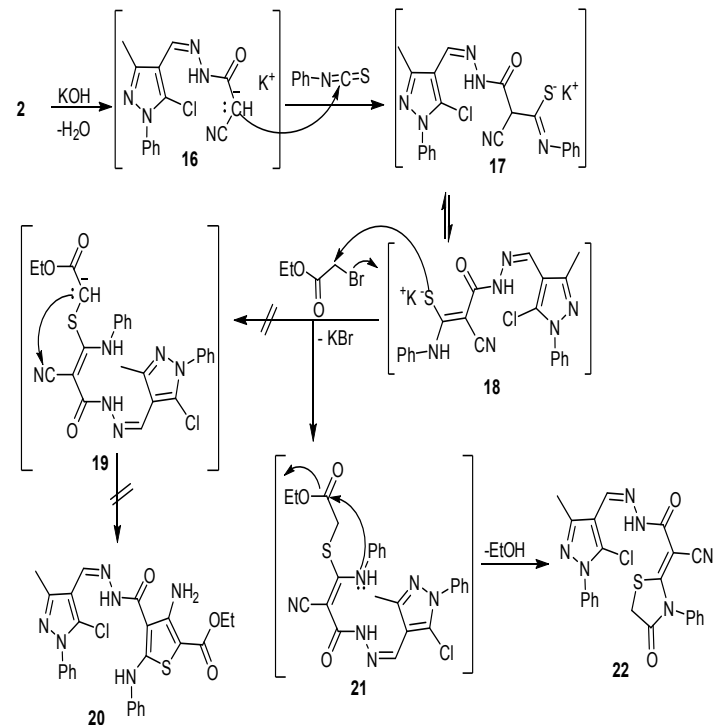

Scheme 5. Reagent and conditions: i-DMF/KOH, stirrer 48 h ii-DMF, stirrer r.t 6 h iii-DMF, stirrer r.t 4 hours

spectral data, an elimination of hydrogen bromide and ethyl alcohol the most plausible mechanistic pathway for prepared compound (22) preferred over compound (20). the proposed mechanism was supported by intense absorption nitrile group band at $2201 \mathrm{~cm}^{-1}$ in IR spectrum , which would be disappeared of compound (20) formed. Whereas the ${ }^{1}$ HNMR spectrum showed no peaks for the characteristics signals of ethyl protons.

\section{Biological activity}

Agar diffusion method used for evolution antimicrobial potency for tested compounds, using the following microorganism: "Gram- positive bacteria: Staphylococcus aureus (ATCC25923) and Bacillus subtilis (ATCC6635), Gram-negative bacteria: Escherichia coli (ATCC 25922) and Salmonella typhimurium (ATCC 14028), Yeast: Candida albicans (ATCC 10231) and Fungus: Aspergillus fumigatus". From Table 1, the compounds 6b, 6c, 8, 12a, 13 and were found to be inactive against all microorganisms while compounds $2,3,6 \mathrm{a}, 12 \mathrm{~b}$ and 22 exhibited moderate activity against some microorganisms only and inactive against others. From the study, of the biological activity of these compounds were found that these compounds containing the unit of pyrazole weak or no effect on microbes. 




\section{CONCLUSION}

In this work, we prepared pyrazolocyanoacetohydrazide derivative (2) as a new stating material Pyrazolo-pyridone (4), pyrazolocheomene (6) and pyrazolo-benzochromene (8) was synthesized via nucleophilic cycloaddition reactions. when substituted aromatic azide was reacted with (2), to give 5-aminotriazole through dipolar cycloaddition reaction mechanism. While, substitution reaction of (2) with diazonium chloride salts afforded (11) and (12). The compound (2) was reacted with phenylisothiocyanate in base medium followed by addition of ethyl bromoacetate afforded the pyrazolothiazole derivative (22). Antimicrobial activity was evaluated for all synthesized compounds the compounds $6 \mathrm{~b}, 6 \mathrm{c}, 8,12 \mathrm{a}, 13$ were exhibited inactive potency against all microorganisms while compounds 2, 3, 6a, 12b and 22 were exhibited moderate activity against some microorganisms Finally, we concluded that, the newly synthesized compounds possess a weak or no effect on microorganisms.

\section{ACKNOWLEDGMENT}

The author would like to thank everyone who helped in the success of this work.

\section{Conflict Of Interest}

The author declare no conflict of interest.

\section{REFERENCES}

1. Hassan, A.; Ahmed, M.; Ali, Khalaf. Eur. J. Chem., 2014, 5(2), 277-286.

2. Luiza, R.; Raquel, R. Pharmaceuticals., 2012, 317-324.

3. Lamberth, C.; Dinges, J. Wiley-VCHVerlag GmBH \& Co. KGaA:Weinheim, Germany., 2012, 175-194.
4. Elguero, J.; Goya, P.; Jagerovic, N.; Silva, A.M. Ital. Soc. Chem., 2002, 52-98.

5. Robin, E. M. ; David, R.G.; Vijayalekshmi. S. Phytochemistry., 2008, 69, 2704-2707.

6. Karthikeyan, M. S.; Holla, B.S.; Kumari, N. S. Eur. J. Med. Chem., 2007, 42, 30-36. 
7. Bandgar, B. P.; Totre, J. V.; Gawande, S. S.; Khobragade, C. N.; Warangkar, S. C.; Kadam, P. D. Bioorg. Med. Chem., 2010, 18(16), 6149-6155.

8. Prakash, O.; Rashmi, P.; Pooja, R.; Kamaljeet, P.; Yogita, D.; Aneja, K. R., Indian J Chem., 2009 , 48B , 563-568.

9. Bekhit, A. A.; Ashour, H. M.; Guemei, A. A. Arch Pharm (Weinheim)., 2005, 338(4), 167-174.

10. Xia, Y.; Fan,C.;Zhao, B.X.;Zhao, J.; Shin, D.S.; Miao, J.Y. Eur. J. Med. Chem., 2008, 43, 2347-2353.

11. Brahmbhatt, D. I.; Ankit, R. K.; Anil, K. P.; Niraj, H. P. Indian. J. Chem., 2010, 49B, 971-977.

12. Michael, J. G.; Carolyn, B. J. Med. Chem., 2000, 43(5), 1034-1040.

13. Zhang, A.;Zhou, J.; Tao, K.; Hou, T.; Jin, H. Bioorg. Med. Chem. Lett., 2018, 28, 3042-3045.

14. Vala, ND.; Jardosh, HH.; Patel, MP. Chin. Chem. Lett., 2016, 27(1), 168-172.

15. Parmar, BD.; Sutariya, TR.; Brahmbhatt, GC.;
Parmar, NJ.; Kant, R.; Gupta, VK.; Murumkar, PR.; Sharma, MK.; Yadav, MR. Molecular. diversity., 2016, 20(3), 639-657.

16. Mondal, G.; Jana, H.; Acharjya, M.; Santra, A.; Bera, P.; Jana, A.; Panja, A.; Bera, P. Med. Chem. Res., 2017, 26(11), 3046-3056.

17. Atta-Allah, SR.; Abou-Elmagd,WS.; Kandeel, KA.; Hemdan, MM.; Haneen, DS.; Youssef, Ahmed, S. J. Chem. Res., 2017, 41(11), 617-623.

18. El-Gamel, NE.; Farghaly, TA. Spectr. Acta., 2013, 115, 469-475.

19. Bondock, S.; Fadaly, W.; Metwally, MA. Eur. J. Med. Chem., 2010, 45(9), 3692-3701.

20. Imran, M.;Bakht, MA.; Samad, A.;Abida A. Tropical. J. Pharm. Res., 2017, 16(5), 1147-1155.

21. Ansari, MI.; Khan, SA. Med. Chem. Res., 2017, 26(7), 1481-1496.

22. Khidre, RE.; Abu-Hashem, AA.; El-Shazly, M. Eur. J. Med. Chem., 2011, 46(10), 5057-5064. 